RECEIVED

DOE/OR 02-1483\&D1

JAN ? 31997

O S T Work Plan

for the Radiological Survey

for the David Witherspoon, Incorporated,

Landfill-1630 Site,

Knoxville, Tennessee

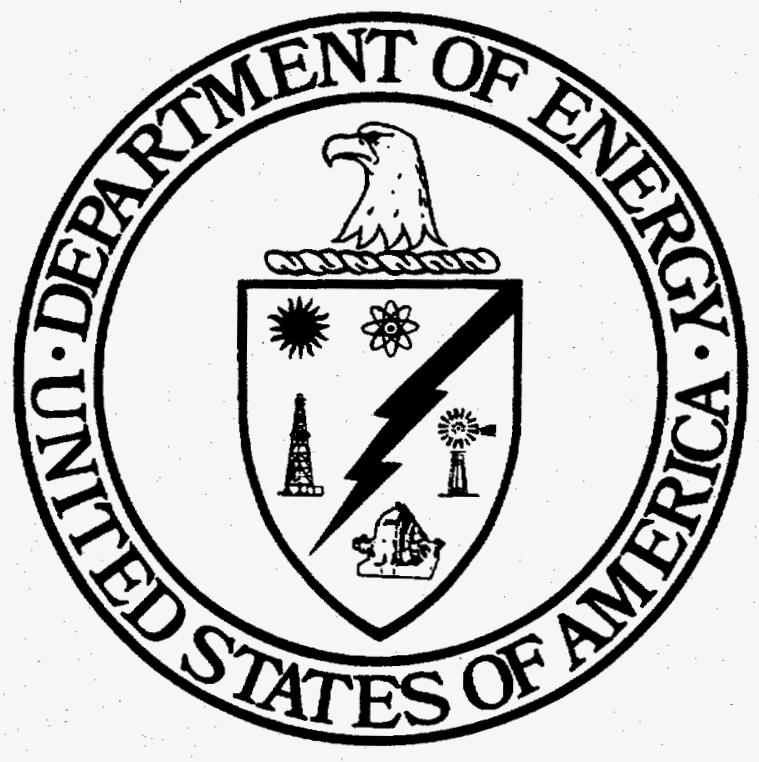




\section{DISCLAMMER}

Portions of this document may be illegible in electronic image products. Images are produced from the best available original document. 


\section{DISCLAIMER}

This report was prepared as an account of work sponsored by an agency of the United States Government. Neither the United States Government nor any agency thereof, nor any of their employees, make any warranty, express or implied, or assumes any legal liability or responsibility for the accuracy, completeness, or usefulness of any information, apparatus, product, or process disciosed, or represents that its use would not infringe privately owned rights. Reference herein to any specific commercial product, process, or service by trade name, trademark, manufacturer, or otherwise does not necessarily constitute or imply its endorsement, recommendation, or favoring by the United States Government or any agency thereof. The views and opinions of authors expressed herein do not necessarily state or reflect those of the United States Government or any agency thereof. 


\title{
Work Plan \\ for the Radiological Survey \\ for the David Witherspoon, Incorporated, \\ Landfill-1630 Site, \\ Knoxville, Tennessee
}

Date Issued-July 1996

\author{
Prepared by \\ Jacobs ER Team \\ 125 Broadway Avenue \\ Oak Ridge, Tennessee \\ under contract DE-AC05-93OR22028 \\ Prepared for \\ U.S. Department of Energy
}

Office of Environmental Restoration and Waste Management 


\section{PREFACE}

The Work Plan for the Radiological Survey for the David Witherspoon, Incorporated, Landfill-1630 Site, Knoxville, Tennessee (DOE/OR/02$1483 \& D 1)$ has been prepared as a supporting document for the Phase II remedial investigation/feasibility study. The work plan identifies the method and requirements for performing the radiological survey to verify the cleanliness of the materials on the site, identify the equipment and debris that can be considered free of radiological contamination, and aid in determining its subsequent disposition. The David Witherspoon, Incorporated, Landfill, located off the U.S. Department of Energy (DOE) Oak Ridge Reservation, is a Tennessee Division of Superfund site. The work is being conducted in accordance with provisions in a Consent Order signed October 6, 1994, between DOE and the Tennessee Department of Environment and Conservation. Although the site is not subject to the Federal Facility Agreement (FFA), the remedial activities will be conducted in a manner consistent with the conditions of the Comprehensive Environmental Response, Compensation, and Liability Act of 1980 . The radiological survey will be performed under Work Breakdown Structure 1.4.12.3.1.03 (Activity Data Sheet 9303, "NonFFA Projects"). The scheduled duration for performing the field activities associated with the radiological survey is 10 weeks. 


\section{CONTENTS}

FIGURES $\ldots \ldots \ldots \ldots \ldots \ldots \ldots \ldots \ldots \ldots \ldots \ldots \ldots \ldots \ldots \ldots \ldots$

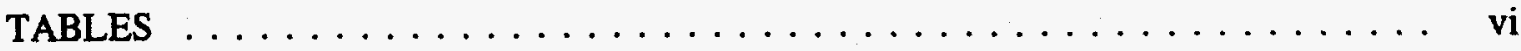

ACRONYMS AND ABBREVIATIONS $\ldots \ldots \ldots \ldots \ldots \ldots \ldots \ldots \ldots$ vii

1. INTRODUCTION $\ldots \ldots \ldots \ldots \ldots \ldots \ldots \ldots \ldots \ldots \ldots \ldots \ldots \ldots \ldots \ldots \ldots$

1.1 BACKGROUND $\ldots \ldots \ldots \ldots \ldots \ldots \ldots \ldots \ldots \ldots \ldots \ldots \ldots$

1.2 PREVIOUS SITE INSPECTIONS AND INVESTIGATIONS $\ldots \ldots \ldots 4$

1.3 SITE DESCRIPTION $\ldots \ldots \ldots \ldots \ldots \ldots \ldots \ldots \ldots \ldots \ldots$

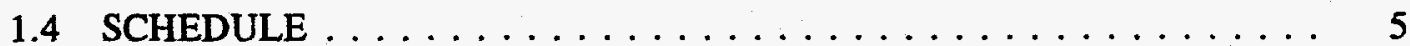

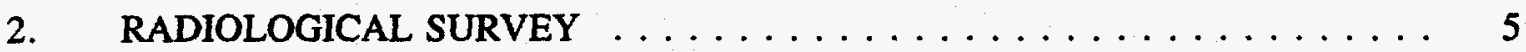

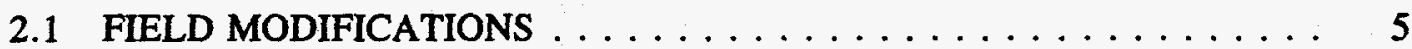

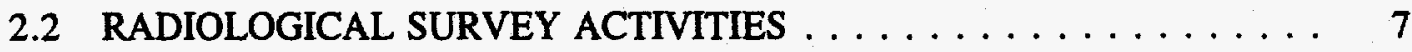

2.2.1 Equipment Radiological Survey $\ldots \ldots \ldots \ldots \ldots \ldots \ldots 7$

2.2.2 Radiological Walkover Survey $\ldots \ldots \ldots \ldots \ldots \ldots \ldots \ldots$

2.3 IMMUNOASSAY FOR PCBs $\ldots \ldots \ldots \ldots \ldots \ldots \ldots \ldots \ldots$

3. QUALITY ASSURANCE/QUALITY CONTROL PROJECT PLAN $\ldots \ldots \ldots 11$

3.1 INTRODUCTION $\ldots \ldots \ldots \ldots \ldots \ldots \ldots \ldots \ldots \ldots \ldots \ldots \ldots$

3.2 QUALIFICATIONS AND TRAINING $\ldots \ldots \ldots \ldots \ldots \ldots \ldots, 12$

3.2.1 Field Technical Representative $\ldots \ldots \ldots \ldots \ldots \ldots \ldots \ldots 13$

3.2.2 Site Health and Safety Officer $\ldots \ldots \ldots \ldots \ldots \ldots \ldots 13$

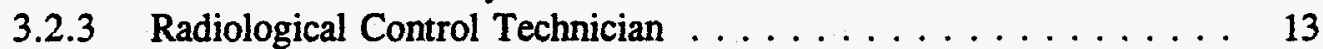

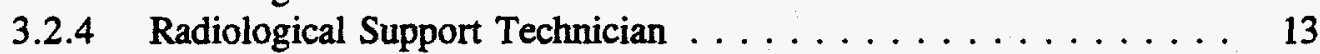

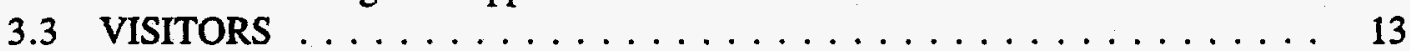

3.4 FIELD EQUIPMENT $\ldots \ldots \ldots \ldots \ldots \ldots \ldots \ldots \ldots \ldots \ldots$

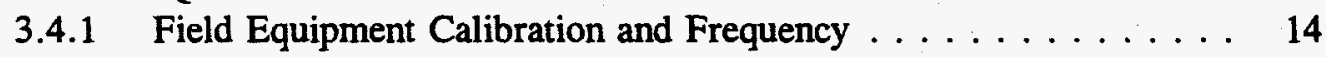

3.4.2 Field Equipment Preventive Maintenance $\ldots \ldots \ldots \ldots \ldots 14$

3.5 INTERNAL QC CHECKS $\ldots \ldots \ldots \ldots \ldots \ldots \ldots \ldots \ldots \ldots$

3.5.1 Field Readiness Assessment $\ldots \ldots \ldots \ldots \ldots \ldots \ldots \ldots 14$

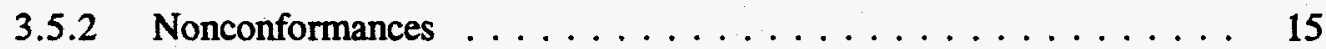

3.6 PERFORMANCE, SYSTEM AUDITS, AND SURVEILLANCE . . . . . 15

4. HEALTH AND SAFETY PLAN $\ldots \ldots \ldots \ldots \ldots \ldots \ldots \ldots$

4.1 INTRODUCTION $\ldots \ldots \ldots \ldots \ldots \ldots \ldots \ldots \ldots \ldots \ldots \ldots \ldots \ldots$

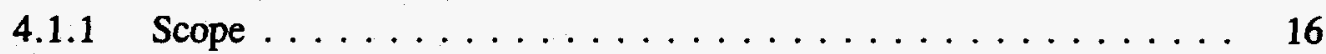

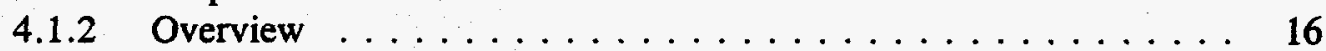

4.2 KEY PERSONNEL AND ORGANIZATION $\ldots \ldots \ldots \ldots \ldots \ldots, 17$

4.2.1 Key Personnel $\ldots \ldots \ldots \ldots \ldots \ldots \ldots \ldots \ldots \ldots \ldots$

4.2.2 Task-Specific Organization $\ldots \ldots \ldots \ldots \ldots \ldots \ldots \ldots \ldots 17$

4.2.2.1 Task manager $\ldots \ldots \ldots \ldots \ldots \ldots \ldots \ldots \ldots, 17$

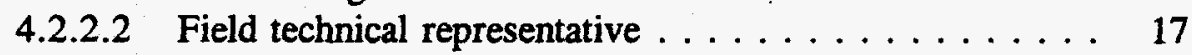

4.2.2.3 Program health and safety manager $\ldots \ldots \ldots \ldots \ldots 17$ 


\section{CONTENTS (continued)}

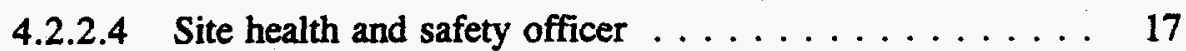

4.2.2.5 Radiological control manager . . . . . . . . . . 18

4.2.2.6 Radiological control specialist ............ 18

4.2.2.7 Radiological control technician . . . . . . . . . 20

4.2.2.8 Radiological support technician $\ldots \ldots \ldots \ldots \ldots \ldots$

4.2.2.9 Field personnel . . . . . . . . . . . . . 20

4.3 HAZARD ASSESSMENT $\ldots \ldots \ldots \ldots \ldots \ldots \ldots \ldots \ldots \ldots$

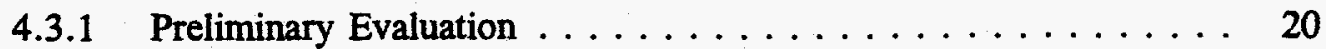

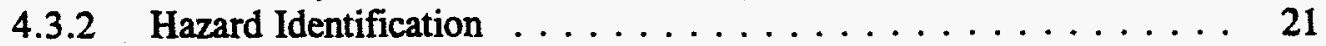

4.3 .3 Physical Hazards . . . . . . . . . . . . . . . . 21

4.3.4 Biological Hazards ..................... 21

4.3.5 Radiological Hazards ...................... 21

4.3.6 Chemical Hazards . . . . . . . . . . . . . . . . . 23

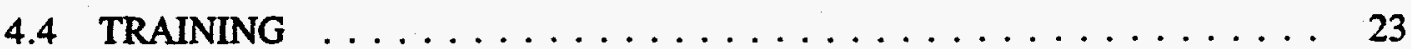

4.5 PERSONAL PROTECTIVE EQUIPMENT $\ldots \ldots \ldots \ldots \ldots \ldots \ldots$

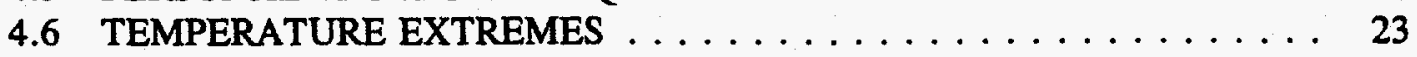

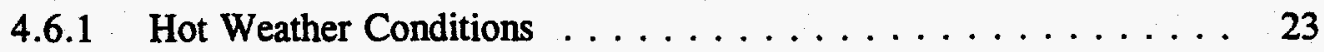

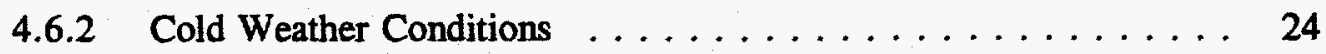

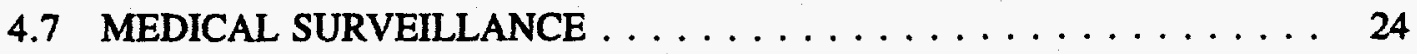

4.7.1 Type and Frequency of Examinations . . . . . . . . . . . 24

4.7.1.1 Baseline (initial) examinations . . . . . . . . . 24

4.7.1.2 Annual examinations ............... 24

4.7.1.3 Baseline (exit) examination ............. 25

4.7.1.4 Postexposure examination ............. 25

4.7 .2 Documentation and Records . . . . . . . . . . . 25

4.8 EXPOSURE MONITORING AND AIR SAMPLING $\ldots \ldots \ldots \ldots \ldots$

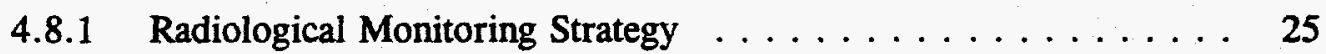

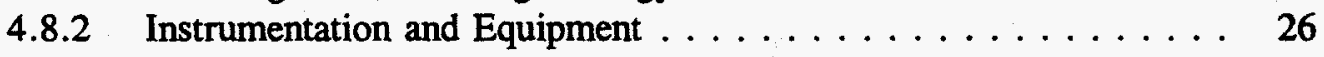

4.8.3 Physical Monitoring . . . . . . . . . . . . . . . 26

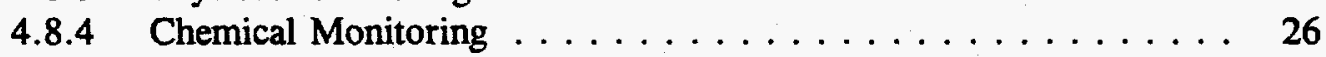

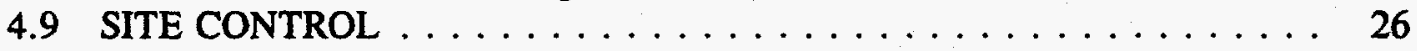

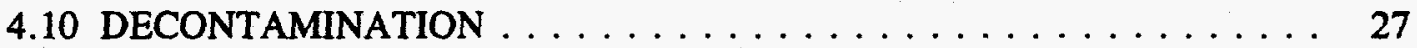

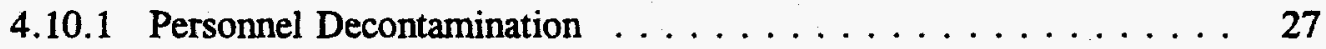

4.10 .2 Equipment Decontamination . . . . . . . . . . . . 27

4.11 EMERGENCY RESPONSE/CONTINGENCY PLAN . . . . . . . . . . 27

4.12 EMERGENCY ACTION PLAN $\ldots \ldots \ldots \ldots \ldots \ldots \ldots \ldots \ldots$

4.12.1 Emergency Telephone Numbers . . . . . . . . . . . . 28

4.12.2 Emergency Precautions . . . . . . . . . . . . . . . 28

4.13 CONFINED SPACE ENTRY $\ldots \ldots \ldots \ldots \ldots \ldots \ldots \ldots \ldots \ldots \ldots$

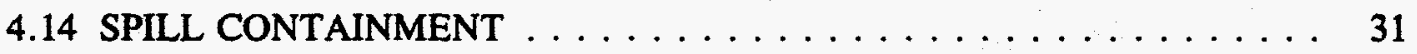

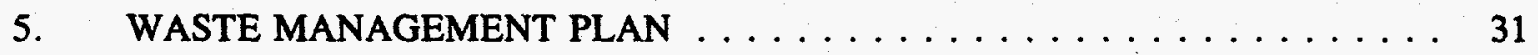

5.1 WASTE-HANDLING RESPONSIBILITIES $\ldots \ldots \ldots \ldots \ldots \ldots \ldots \ldots$

5.1 .1 Jacobs ER Team .................... 31

5.1 .2 Lockheed Martin Energy Systems . . . . . . . . . . . . 31 


\section{CONTENTS (continued)}

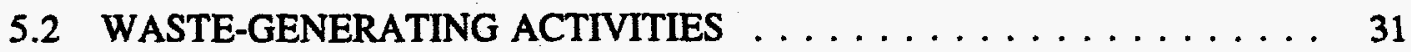

5.3 WASTE HANDLING AND CHARACTERIZATION $\ldots \ldots \ldots \ldots \ldots$.

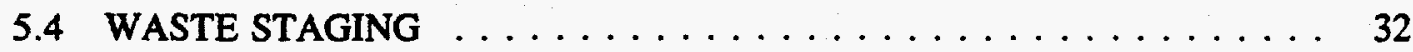

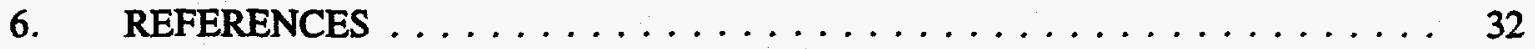




\section{FIGURES}

Figure No.

Page

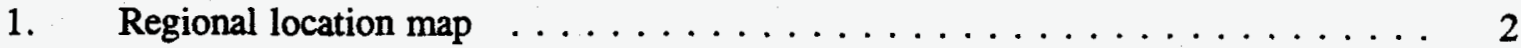

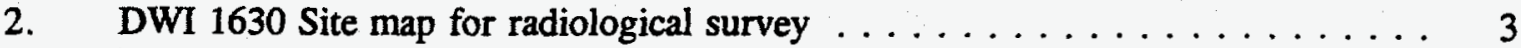

3. Proposed schedule for DWI 1630 Site radiological survey $\ldots \ldots \ldots \ldots \ldots$

4. Process flow diagram for equipment radiological survey $\ldots \ldots \ldots \ldots \ldots$

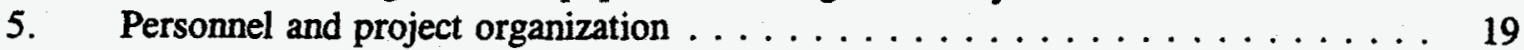

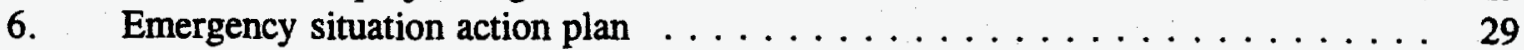

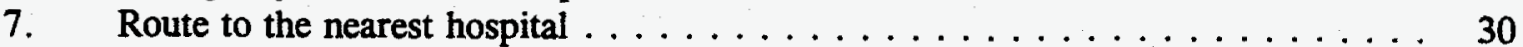

TABLES

Table No.

Page

1. Instrumentation to be used for the radiological survey of DWI 1630 Site . . . . 8

2. Key personnel for the radiological survey of the DWI 1630 Site $\ldots \ldots \ldots \ldots$

3. Hazard identification and controls for the DWI 1630 Site $\ldots \ldots \ldots \ldots 22$ 


\section{ACRONYMS AND ABBREVIATIONS}

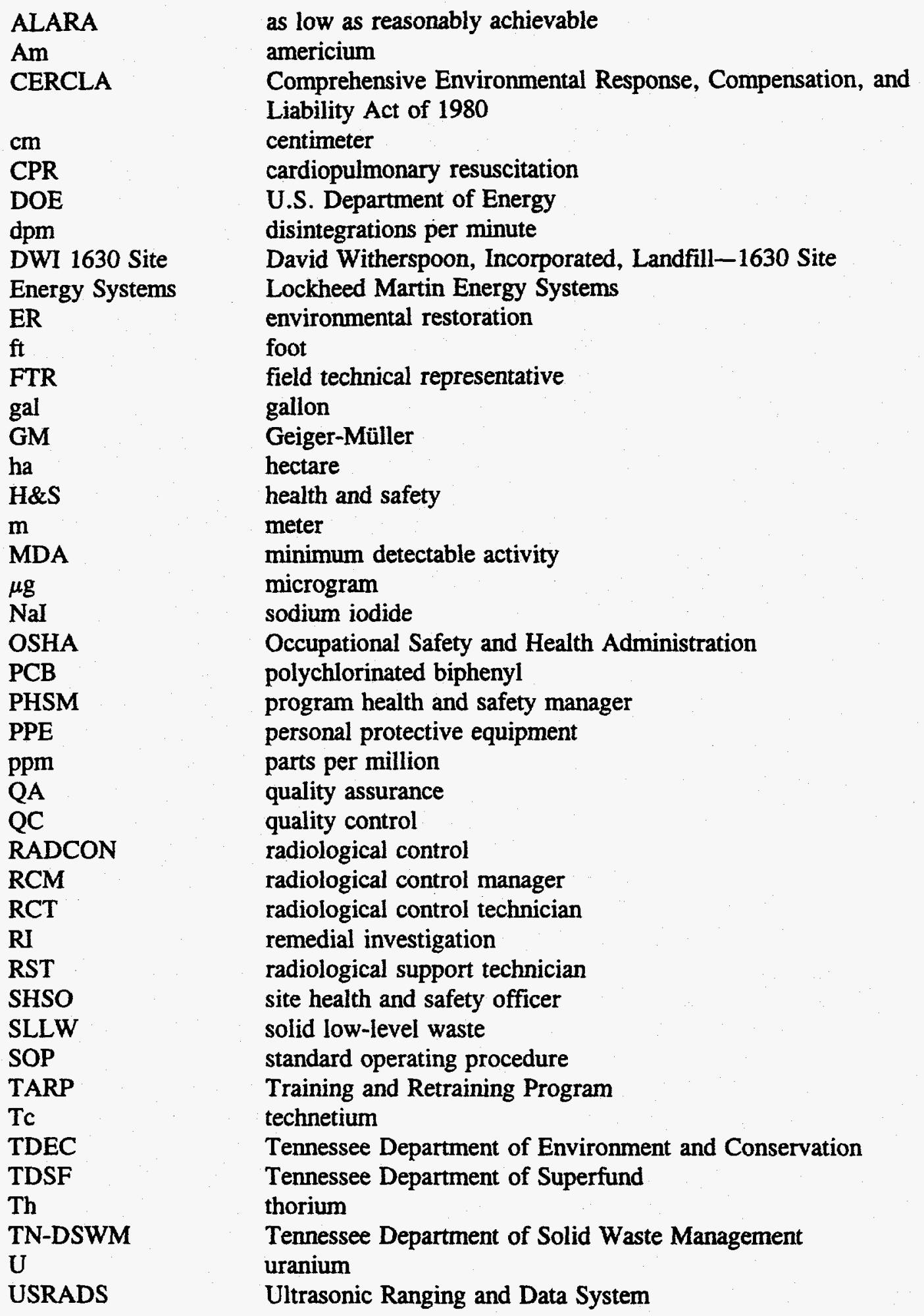




\section{INTRODUCTION}

This work plan establishes the methods and requirements for performing a radiological survey at the David Witherspoon, Incorporated, Landfill-1630 Site (DWI 1630 Site) (see Figs. 1 and 2) in accordance with requirements under the Comprehensive Environmental Response, Compensation, and Liability Act of 1980 (CERCLA). The radiological survey will identify the radiological contamination level of the equipment and debris stored at the DWI 1630 Site. The data generated from the survey activities will support the decisions for characterization of the equipment/debris and aid in subsequent disposition and waste handling. The survey activities to be performed under this work plan include an equipment radiological survey, a walkover survey, and an immunoassay testing for polychlorinated biphenyls (PCBs).

This work plan includes a quality assurance (QA)/quality control (QC) project plan, a health and safety (H\&S) plan, and a waste management plan.

\subsection{BACKGROUND}

From 1966 to 1969 , the Atomic Energy Commission licensed David Witherspoon, Incorporated, to receive scrap metal contaminated with natural and enriched uranium from the U.S. Department of Energy (DOE) Oak Ridge Reservation. Additionally, from early 1950 until the site closed in 1974, the landfill was used to dispose of solid and liquid wastes from salvaging materials and industrial wastes. Other refuse included pallets, cardboard, foundry sand, old tires, and dust from industrial dust collectors. Industrial wastes disposed of in the landfill include transformer oils containing PCBs and low-level radioactive contaminated metals.

On January 31, 1973, the Tennessee Department of Health and Environment [now the Tennessee Department of Environment and Conservation (TDEC)] issued a Commissioner's Order for the site to be closed by May 1, 1973. Between February 5, 1973, and July 16, 1973, the landfill owner submitted several closure plans, but the state approved none of them because of the deficiencies in the plans. On August 3, 1973, the Knox County Chancery Court ordered a schedule for closing the site. On August 16, 1973, a proposed closure plan was submitted by David Witherspoon, Incorporated, and reviewed by the Tennessee Department of Solid Waste Management (TN-DSWM). TN-DSWM found the proposed plan to be acceptable. The site was reportedly closed in 1974, but there is evidence that disposal activities continued until 1983 (TDSF 1990). 


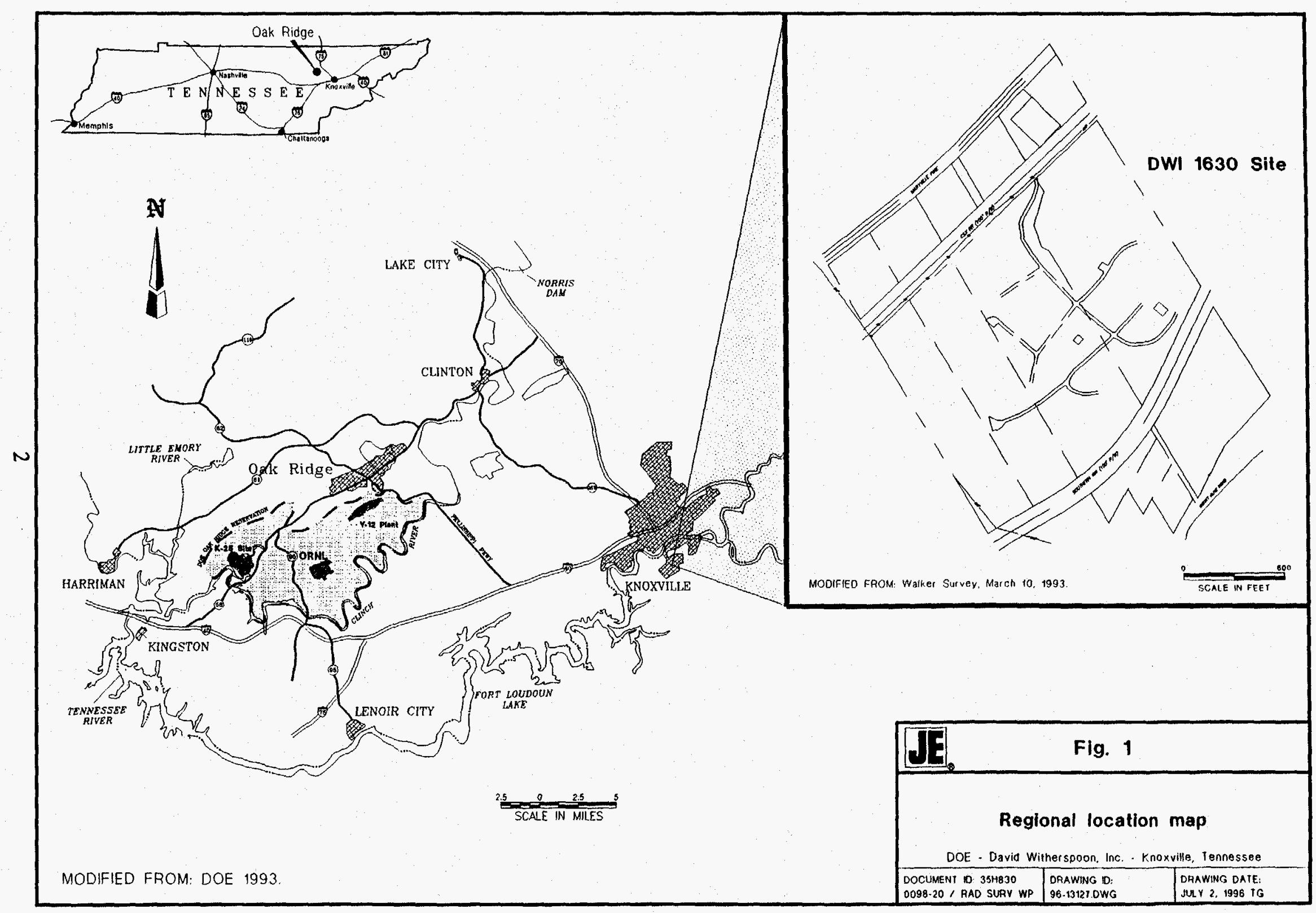




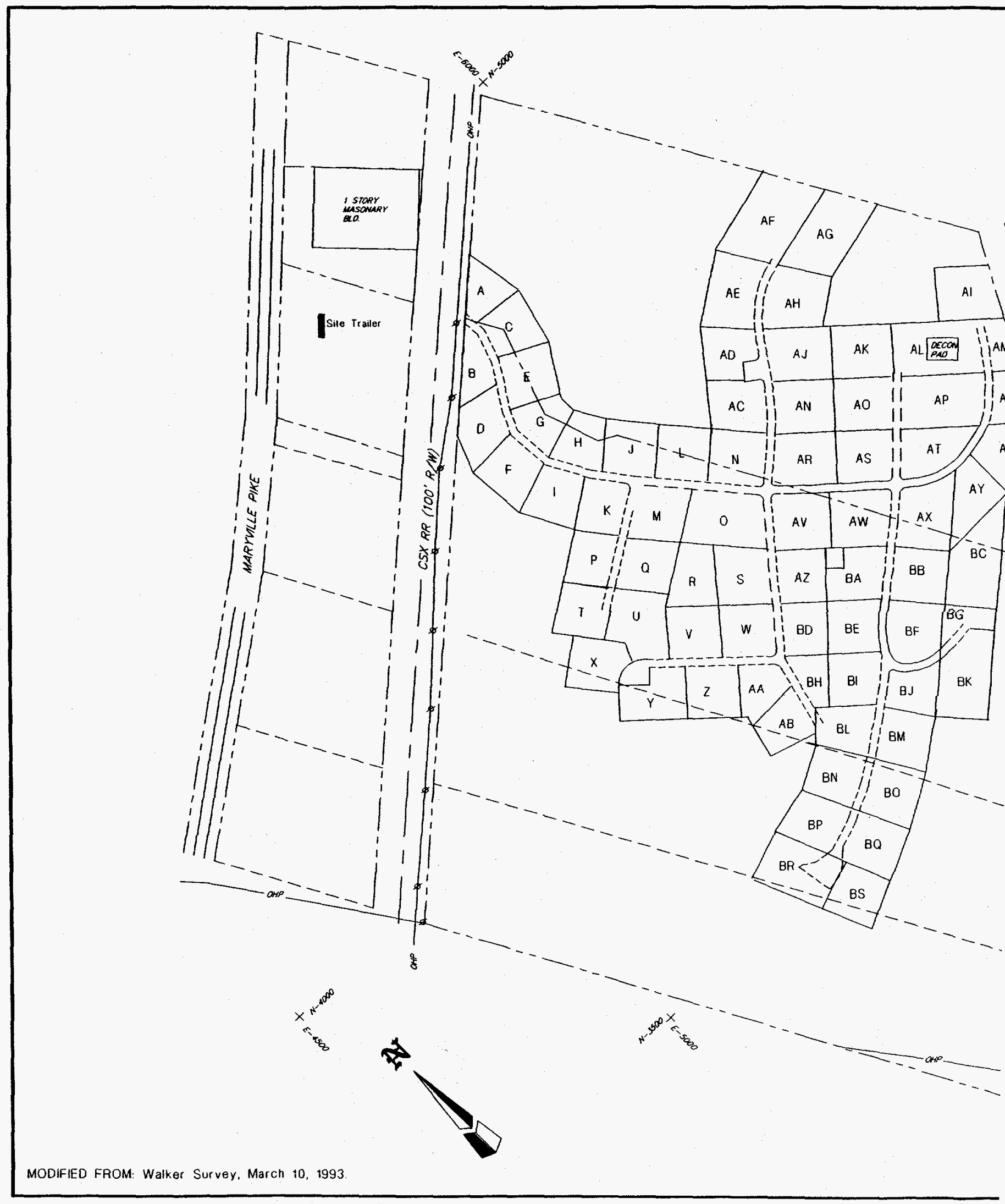


On October 6, 1994, TDEC and DOE entered into a final Consent Order for the remediation of the landfill site. DOE has agreed to conduct all remedial activities in a manner consistent with CERCLA.

TDEC does not have a restraining order against the landfill owner to prevent him from accessing the site. Consequently, materials or items may be brought or removed from the site without the knowledge or consent of TDEC or DOE. To establish a baseline, DOE developed under a separate work plan an inventory list of materials and items on the site. Under this work plan, DOE will perform a radiological survey to identify the equipment and debris that can be considered free of radiological contamination to aid in determining its subsequent disposition. Additionally, DOE will perform a radiological walkover of the landfill site to determine the nature and extent of any surface radioactive contamination.

\subsection{PREVIOUS SITE INSPECTIONS AND INVESTIGATIONS}

Two site inspections have been performed at the DWI 1630 Site. Between 1989 and 1990 , the Tennessee Department of Superfund (TDSF) conducted a preliminary site inspection to identify the possible migration pathways for the closure of the site (TDSF 1990). Twelve samples ( 3 surface water samples, 2 sediment samples, 2 groundwater samples, and 5 soil samples) were collected and analyzed for inorganics, organics, pesticides, and PCBs. No contaminants were detected significantly above the standards for all samples with the exception of sediment and two composite soil samples. However, during the inspection, a newly disturbed area was discovered. Subsequently, a radiation survey was conducted and radioactive contamination was confirmed. Analytical results of soil samples indicated elevated levels of ${ }^{235} U$, ${ }^{234} \mathrm{Th}$, and ${ }^{241} \mathrm{Am}$ (PRC 1993).

During 1992 to 1993, PRC Environmental Management, Inc., performed preliminary remedial investigation (RI) activities under the assignment of TDSF. Samples from this investigation were analyzed for inorganics, volatiles/semivolatiles, pesticides, and PCBs. Elevated levels of metals and PCBs were found in all samples. An analysis for radiological constituents was not performed.

\subsection{SITE DESCRIPTION}

The landfill is located at 1630 Old Maryville Pike, between Kingsley Station and Mount Olive Communities, in Knox County, Tennessee. The landfill site and surrounding property encompass 19.43 ha (48 acres), consisting of five separate tracts of land in a residential and commercial mixed-use area. Approximately 8.1 ha (20 acres) contain buried and surface debris, 
including dismantled vehicles, equipment, scrap metal, drums, and miscellaneous trash. This debris is in addition to the refuse disposed of in the actual landfill, which occupies approximately 1.4 ha (3.4 acres). The site is bounded to the south by Southern Railroad tracks and on the north by CSX Railroad tracks and the Screen Arts Superfund site (TND063184972). Residential and some industrial areas are located to the north and south of the site beyond the railroad tracks. Land to the east and west of the site is undeveloped. Vehicular access to the landfill from Old Maryville Pike is controlled through a locked gate, but pedestrian access from all other directions is uncontrolled (PRC 1993).

\subsection{SCHEDULE}

The schedule for the radiological survey activities (Fig. 3) incorporates the field survey, documentation, and review of all requirements associated with this survey activity. The work plan for the radiological survey at the DWI 1630 Site is scheduled for submittal to TDEC for review July 9, 1996. The final work plan will be issued August 1, 1996. Field survey activities are scheduled for August 12-October 21, 1996.

\section{RADIOLOGICAL SURVEY}

This radiological survey will determine the radiological contamination of the items inventoried during the equipment inventory field activity. The nature and extent of radiological contamination of the ground surface will also be determined by completing a radiological walkover of the site. Additionally, the PCB immunoassay test will also be conducted on site. The results of the radiological survey will be used to determine the potential disposition of the equipment.

\subsection{FIELD MODIFICATIONS}

Field modifications to this work plan can be implemented by the field technical representative (FTR), provided the following conditions are met:

- For issues involving the survey, the radiological control manager (RCM) is consulted.

- For other issues, the task or QA manager is consulted (depending upon the type of issue).

- Changes will not adversely affect the quality of the work. 


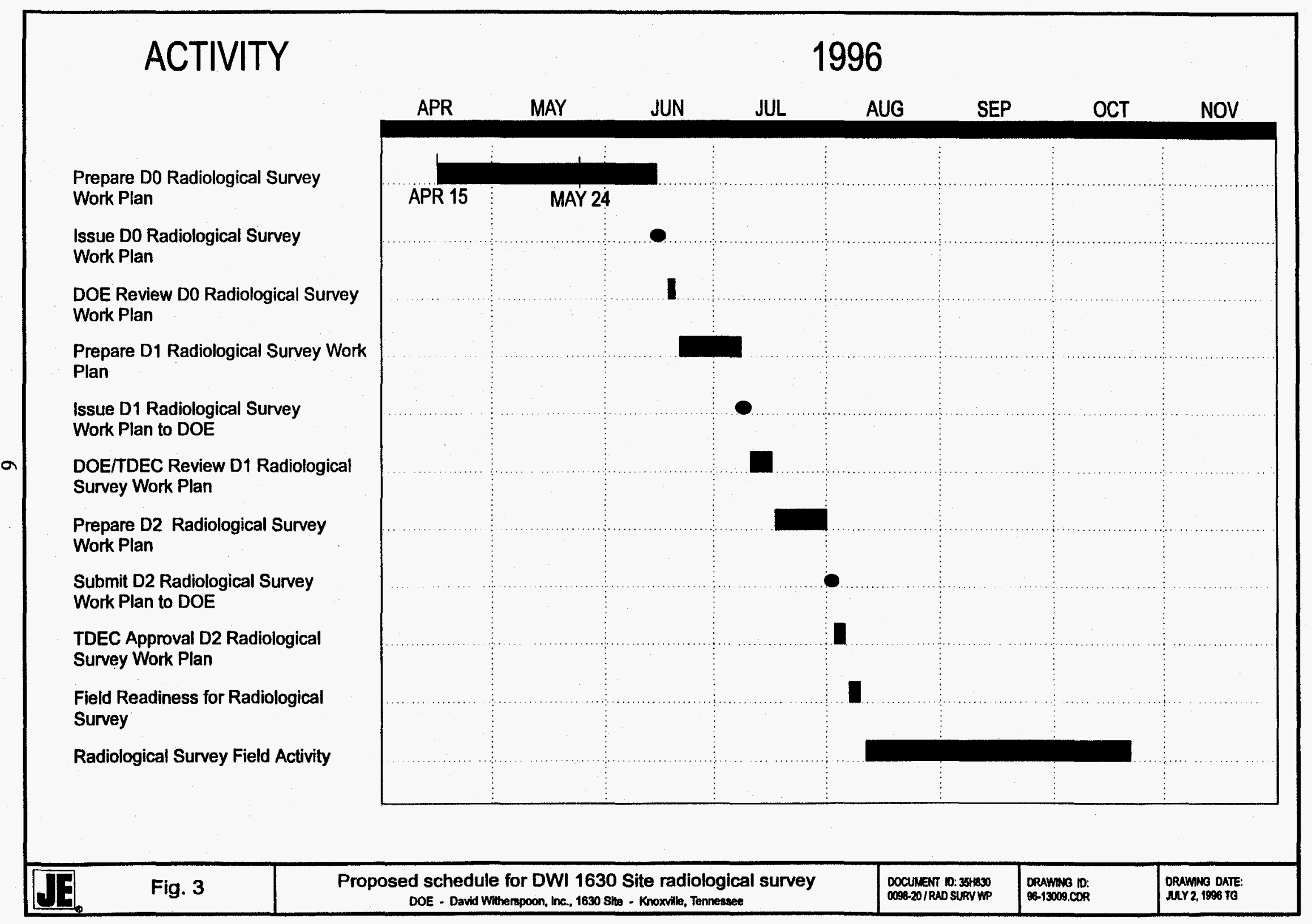


- The modifications adhere to the intent and objectives of the survey.

- Exact changes are recorded in the FTR logbook.

Before changes are made, the FTR and the applicable supervisor will analyze the impact the change may have, including any future impacts involving data assessment. Changes considered to have major impacts will be approved verbally and documented in writing by the DOE program manager. Any field modifications to the H\&S plan must be approved by the Jacobs Environmental Restoration (ER) Team H\&S program manager. The DOE ER H\&S program manager will be copied on all such changes and will make comments or provide input if he/she should deem this necessary.

\subsection{RADIOLOGICAL SURVEY ACTIVITIES}

The survey activities to be performed under this work plan include an equipment radiological survey and a radiological walkover survey. Before any survey begins, materials will be categorized into populations. Populations may include single items (i.e., storage tanks, cars, or other large items) or groups of many similar items (i.e., pallets of scaffolding or piles of catalytic converters). All identified populations will be surveyed for direct and removable radiological contamination. The site grounds will be surveyed for surface radiological contamination.

\subsubsection{Equipment Radiological Survey}

The Jacobs ER Team will use a three-step process to perform the equipment radiological survey using the instruments identified in Table 1 (see Fig. 4). The first step will be performed with a sodium iodide (NaI) detector. The Jacobs ER Team will use Nal detectors according to Standard Operating Procedure (SOP) H\&S-11.3.6, "Sodium Iodide Detector: Calibration and Usage." The radiological control technician (RCT) or radiological support technician (RST) will first determine background in the vicinity of the population, looking specifically for any increases in background attributed to other materials, items, or areas. Once the background is determined, the RCT or RST will then scan the population, looking for any increases in activity above background. If any areas are detected that exceed twice the background reading, which is determined by consultation with an RCT, 100 percent of the population must be surveyed.

If no areas are found with the $\mathrm{NaI}$ detector that exceed background, the second step will be performed with a Geiger-Müller (GM) detector, also referred to as a pancake probe. The Jacobs ER Team uses GM detectors according to SOP H\&S-11.3.1, "Geiger-Müller Detector: 
Table 1. Instrumentation to be used for the radiological survey of DWI 1630 Site, Knoxville, Tennessee

\begin{tabular}{|c|c|c|c|c|c|}
\hline \multirow[t]{2}{*}{ 3010, } & \multicolumn{2}{|c|}{$86 y_{10}$} & \multirow[t]{2}{*}{ Hon } & \multicolumn{2}{|c|}{$(1,1 \times 1 \% 115,14$} \\
\hline & א.1. & Won & & $1+1,1,131$ & 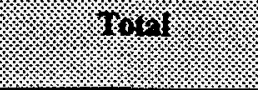 \\
\hline Pancake GM & Ludlum 2221 & $\begin{array}{l}\text { Ludlum 44-9 } \\
\text { (or 44-40) }\end{array}$ & $\approx 15 \%$ & $\begin{array}{c}190-220 \mathrm{dpm} / \\
100 \mathrm{~cm}^{2}\end{array}$ & $\begin{array}{c}1,200-1,400 \mathrm{dpm} / \\
100 \mathrm{~cm}^{2}\end{array}$ \\
\hline Alpha scintillation & Ludlum 2221 & Ludlum 43-5 & $\approx 10 \%$ & $\begin{array}{c}30-100 \mathrm{dpm} / \\
100 \mathrm{~cm}^{2}\end{array}$ & $\begin{array}{c}60-200 \mathrm{dpm} / \\
100 \mathrm{~cm}^{2}\end{array}$ \\
\hline $\begin{array}{l}\text { NaI gamma } \\
\text { scintillator }\end{array}$ & Ludlum 2221 & Ludlum 44-10 & NA & NA & NA \\
\hline $\begin{array}{l}\approx=\text { approximately } \\
\mathrm{Im}=\text { centimeter } \\
\mathrm{ipm}=\text { disintegrations } \\
\mathrm{GM}=\text { Geiger-Müller }\end{array}$ & minute & \multicolumn{4}{|c|}{$\begin{array}{l}\mathrm{MDA}=\text { minimum detectable activity } \\
\mathrm{NA}=\text { not applicable } \\
\mathrm{NaI}=\text { sodium iodide } \\
\%=\text { percent }\end{array}$} \\
\hline
\end{tabular}

Calibration, Operation, and Usage." The Jacobs ER Team performs surveys according to SOP H\&S-11.4.1, "Radiological Contamination Surveys." Surveys will be made with GM detectors rather than detectors that respond only to alpha radiation. Measurements of alpha radiation on weathered, rusted, greasy, or irregular surfaces are biased low because of the low penetrating power of alpha radiation. Previous sampling and site history at DWI 1630 Site indicates that uranium and its associated decay products have been the primary radioactive contaminant of concern. The uranium decay products also emit one or more beta particles or gamma ray per decay (PRC 1993). These daughter products are always present with the uranium parent. GM detectors respond to the more penetrating beta and gamma radiation as well as alpha radiation, thus detecting contamination reliably and providing a conservative upper estimate of any contamination present. Additionally, the efficiencies for the GM detectors are determined using a ${ }^{99} \mathrm{Tc}$ source that gives off a beta particle consistent in energy levels with uranium. The RCT or RST will first determine background in the vicinity of the population, looking specifically for any increases in background attributed to other materials, items, or areas. The RCT or RST will then survey the population at biased areas where contamination may collect. Biased areas include areas where water has collected, oil stained areas, or areas where the population has contacted the ground. If any of the surveyed biased areas exceed the minimum detectable activity (MDA), 100 percent of the population must be surveyed.

If no biased areas exceeding MDA are found with the GM detector, the third step will also be performed with a GM detector. The RCT or RST will survey 10 percent of the entire population. The RCT or RST will determine 10 percent of the population by either counting the 


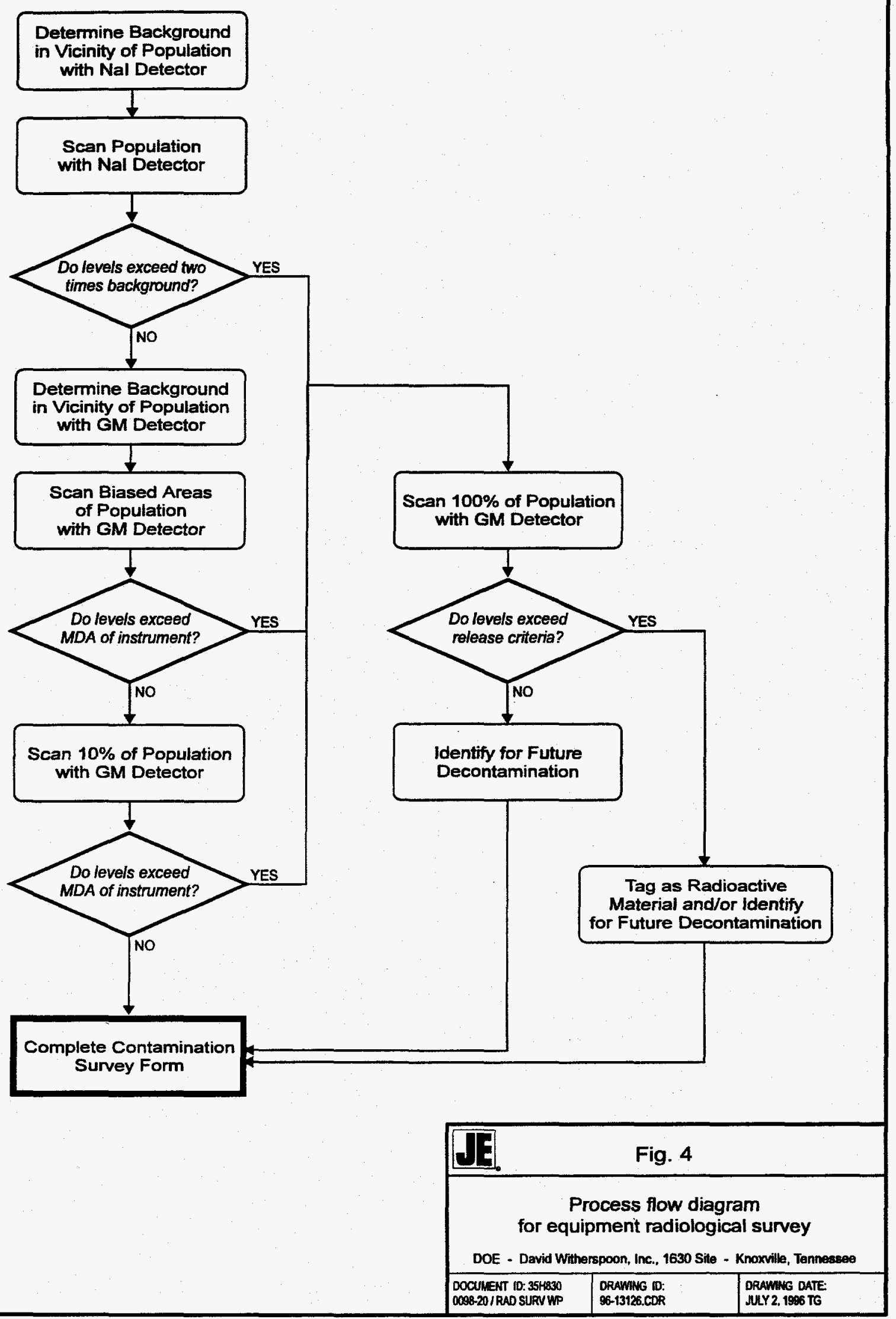


items and surveying 10 percent of them or, for populations of single items, will survey 10 percent of the surface area. If any of the selected areas surveyed exceed the MDA, 100 percent of the population must be surveyed.

In addition to surveys with the GM detector, a confirmatory survey will be performed with an alpha scintillation detector. The Jacobs ER Team uses alpha detectors according to SOP H\&S11.3.2, "Alpha Detector: Calibration, Operation, and Usage." The RCT or RST will survey populations that exceeded the MDA for the GM detectors or, at a minimum, 1 out of 20 of all populations. The RCT or RST will survey the population at the area of the highest GM detector readings or, if all areas are less than MDA, at one of the biased areas.

The items that exceed $1,000 \mathrm{dpm} / 100 \mathrm{~cm}^{2}$ removable or $5,000 \mathrm{dpm} / 100 \mathrm{~cm}^{2}$ total contamination as specified in U.S. Nuclear Regulatory Commission Regulatory Guide 1.86 will be considered radiologically contaminated. Those items will be tagged with an identifying mark or label such as " $\mathrm{X}$ " or by using a contaminated material tag. Contamination survey forms will also be completed to identify the location of the items.

\subsubsection{Radiological Walkover Survey}

The Jacobs ER Team will survey the ground surface at DWI 1630 Site. The survey will be conducted according to SOP H\&S-11.4.2, "Radiation Exposure Monitoring," or equivalent. The NaI detector will be used in this survey. The performance will be conducted in accordance with SOP H\&S-11.3.6 or equivalent.

The walkover survey will be conducted in a grid system established in the previous inventory activities. The grids are approximately 30.5 by $30.5 \mathrm{~m}(100$ by $100 \mathrm{ft})$. During the walkover survey, an RST will survey each grid by walking parallel lines through the area. The walkover survey may also be conducted by a subcontractor using an Ultrasonic Ranging and Data System (USRADS). The USRADS will provide a detailed layout of site indicating qualitative levels of radiation.

\subsection{IMMUNOASSAY FOR PCBS}

Only the populations that show the residue of oil stains will be wipe sampled for PCB analysis. The analysis will be performed on site using immunoassay test kits, a semiquantitative test recommended by the PCB disposal section in TSCA. The test gives an absence or presence indication at the detection levels chosen. The immunoassay test that will be conducted at the DWI 1630 Site will be sensitive to the concentration of PCBs at $10 \mu \mathrm{g} / 100 \mathrm{~cm}^{2}(0.5 \mathrm{ppm})$ or higher. Samples that show no positive results at this detection limit will be recorded as 
$<10 \mu \mathrm{g} / 100 \mathrm{~cm}^{2}$. Items exceeding this limit will be marked as "PCB" or tagged. This analysis may also be performed by a contracted laboratory, whichever is more practical and/or economical.

\section{QUALITY ASSURANCE/QUALITY CONTROL PROJECT PLAN}

\subsection{INTRODUCTION}

The goal of the Jacobs ER Team is to provide radiological survey data of appropriate quality for site characterization. This QA/QC project plan describes activities associated with conducting radiation surveys at DWI 1630 Site in Knoxville, Tennessee. The Jacobs ER Team will use the following SOPs on this task:

- FS-1.5, "Field Readiness Review Checklist"

- FS-1.6, "Training and Instructions for Field Technical Representatives"

- FS-2.2.1, "Field Logbook Entries"

- FS-11.1, "Minimization, Collection, and Storage of IDW"

- FS-12.0, "Decontamination"

- H\&S-5.1.1, "Preparation of Task Hazard Analysis"

- H\&S-5.1.2, "Conduct of Preliminary Site Evaluations"

- H\&S-6.0, "Personal Protective Equipment"

- H\&S-9.3.1, "Heat Stress Monitoring”

- H\&S-9.3.2, "Cold Stress Monitoring"

- H\&S-11.0, "Radiation Protection"

- H\&S-11.1.1, "ALARA Implementation"

- H\&S-11.1.2, "Radiological Work Permits"

- H\&S-11.2.1, "External Dosimetry"

- H\&S-11.3, "Radiological Instrumentation"

- H\&S-11.3.1, "Geiger-Müller Detector: Calibration, Operation, and Usage"

- H\&S-11.3.2, "Alpha Detector: Calibration, Operation, and Usage”

- H\&S-11.3.3, "Alpha-Beta Sample Counter: Calibration and Usage”

- H\&S-11.3.4, "Ionization Chamber: Calibration and Usage"

- H\&S-11.3.5, "Micro-R Meter: Calibration and Usage"

- H\&S-11.3.6, "Sodium Iodide Detector: Calibration and Usage"

- H\&S-11.4.1, "Radiological Contamination Surveys"

- H\&S-11.4.2, "Radiation Exposure Monitoring" 
- H\&S-11.4.3, "Radiological Air Sampling and Monitoring"

- H\&S-11.4.4, "Personnel Contamination Monitoring (Frisking)"

- H\&S-11.6.1, "Personnel, Equipment, and Materials Radiological Decontamination"

- QA-3.0, "Training”

- QA-4.0, "Quality Assessments"

- QA-7.0, "Control of Nonconforming Items and Services"

\subsection{QUALIFICATIONS AND TRAINING}

This section establishes requirements to ensure that personnel have the training to work safely in and around radiological areas and to maintain their individual radiation exposure and the radiation exposures of others as low as reasonably achievable (ALARA). The Jacobs ER Team follows ALARA practices according to SOP H\&S-11.1.1. Each of the crew members must complete required reading assignments and meet minimum training requirements. Required reading assignments include SOPs specific to the field work and the work plan. Minimum training requirements include:

- current 40-hour Occupational Safety and Health Administration (OSHA) or 8-hour refresher training,

- General Employee Radiological Training,

- Radiological Worker II, and

- training on the site-specific H\&S plan.

All Jacobs ER Team field personnel participate in the medical monitoring program as outlined in Section 4.7 for this activity in accordance with 29 Code of Federal Regulations 1910.120. Additionally, all field personnel involved in this activity participate in the Jacobs ER Team Training and Retraining Program (TARP) as outlined in the Jacobs ER Team Radiological Control (RADCON) Manual, Oak Ridge, Tennessee (Jacobs ER Team 1996). The Jacobs ER Team TARP consists of a DOE RCT Core Academics challenge exam, classroom theory, and practical training such as survey techniques and radiological instrumentation training. Personnel performing PCB immunoassay are required to have performance-based training. Additional qualifications for each position are given in the following Sections 3.2.1-3.2.4. 


\subsubsection{Field Technical Representative}

The FTR must have relevant experience at managing a field operation of similar complexity. He/she must also have current 8-hour OSHA supervisory training. In addition, the FTR must have completed the prefield orientation as described in SOP FS-1.6.

\subsubsection{Site Health and Safety Officer}

The site health and safety officer (SHSO) must have 1 year of H\&S work experience in field projects of similar size and nature or documented training as an SHSO for low hazard projects that have been approved by the program health and safety manager (PHSM). The SHSO must have demonstrated the ability to implement a site H\&S plan and ensure compliance with its requirements. Current 8-hour OSHA supervisor training, first aid, cardiopulmonary resuscitation (CPR), and bloodborne pathogen training are also required for the SHSO.

\subsubsection{Radiological Control Technician}

The RCT must have a minimum of 2 years of radiological experience. A degree in applied health physics or related field may substitute for 1 year. The RCT may also be the SHSO, if they have the appropriate qualifications.

\subsubsection{Radiological Support Technician}

The RST may be any field team member who has been trained to support radiological activities associated with a project under the Jacobs ER Team TARP.

Employee training is documented according to SOP QA-3.0. Training records are maintained by the Jacobs ER Team training coordinator at the Jacobs Technical Center. A computer-generated copy of the training records will be kept at the site by the SHSO while performing work in the field.

\subsection{VISITORS}

Visitors who enter the controlled area (the entire DWI 1630 Site) will receive a H\&S briefing that includes material from the H\&S plan and the crew's daily H\&S briefing. Information may be communicated by handout to personnel entering the site. The SHSO will document the briefing on Form JOR-QA-8, "Training Records." 


\subsection{FIELD EQUIPMENT}

\subsubsection{Field Equipment Calibration and Frequency}

Radiological instruments must be calibrated annually and response checked daily or before use according to SOP H\&S-11.3. The RCT will maintain copies of the calibration records and daily response check sheets. Daily response checks are documented on Form JOR-H\&S-37, "Radiation Detector Operational Check Form," for instruments reading in units of counts per minute and Form JOR-H\&S-39, "Exposure Rate Instrument Operational Check Form," for instruments reading in units of milliroentgen or microroentgen per hour. The following SOPs apply to specific instruments that may be used at the site:

- H\&S-11.3.1, "Geiger-Müller Detector: Calibration, Operation, and Usage"

- H\&S-11.3.2, "Alpha Detector: Calibration, Operation, and Usage"

- H\&S-11.3.3, "Alpha-Beta Sample Counter: Calibration and Usage”

- H\&S-11.3.4, "Ionization Chamber: Calibration and Usage"

- H\&S-11.3.5, "Micro-R Meter: Calibration and Usage”

- H\&S-11.3.6, "Sodium Iodide Detector: Calibration and Usage"

\subsubsection{Field Equipment Preventive Maintenance}

Radiological instruments are maintained according to SOP H\&S-11.3. This SOP requires the use of components and procedures at least as stringent as those specified by the manufacturer. Additionally, preventive and corrective maintenance is documented on Form JOR-H\&S-40, "Radiation Detector Maintenance Log."

\subsection{INTERNAL QC CHECKS}

\subsubsection{Field Readiness Assessment}

A field readiness assessment will be conducted before mobilization to determine the status of the preparation necessary to complete the task. The assessment will be completed in accordance with SOP FS-1.5. This SOP covers approved plans, clearances, site access, other applicable SOPs, training, assembly of materials and equipment, waste management, H\&S, analytical services, and QA. 


\subsubsection{Nonconformances}

A nonconformance is a variance from regulation, approved requirements, or procedures that adversely affects safety, durability, performance, or any other basic objective impacting the quality of the work performed. Nonconformances can be identified by field personnel and by QA personnel. Nonconformances identified by field personnel will be handled in accordance with SOP QA-7.0. Nonconformances identified through Jacobs ER Team audits will be handled in accordance with SOP QA-4.0. Nonconformances identified by DOE QA personnel will be immediately brought to the attention of the Jacobs ER Team QA manager, who will take immediate corrective action and report on such action within the time period designated by DOE.

If a nonconformance is identified in action and can be brought into conformance, the problem may be rectified by verbal instruction and noted in the field logbook. If a nonconformance is identified after the procedure is complete, the person who identified the nonconformance will originate a nonconformance report.

\subsection{PERFORMANCE, SYSTEM AUDITS, AND SURVEILLANCE}

The field activities associated with the DWI 1630 Site radiological survey will last approximately 10 weeks. The Jacobs ER Team QA manager or designee shall make site visits to observe the performance of the field team during this period. Field system audits typically consist of an evaluation of SOPs and the degree to which they are being followed, an evaluation of work areas and activities, and a review of project documentation.

The field surveillance is designed to provide rapid feedback to the task team concerning QA compliance and to facilitate corrective action. Field surveillances typically consist of an evaluation of the SOP, an assessment of compliance to approved SOPs, an evaluation of the work areas and survey activities, and a review of field documentation. Items subject to review during these surveillances include, but are not limited to, (1) field logbooks, (2) H\&S training records, and (3) field data logs.

Reports to document the findings of each surveillance will be written and will include:

- any significant QA problems and recommended solutions and

- the outcome of any corrective actions taken to resolve previously stated problems. 
In addition, the QA manager will report whenever actions must be taken as a result of failure to achieve data acceptance criteria. Any significant $Q A$ problems will be identified and reported, and options for changing or modifying the program will be discussed.

\section{HEALTH AND SAFETY PLAN}

\subsection{INTRODUCTION}

This H\&S plan provides a written assessment of potential H\&S hazards associated with the activities the Jacobs ER Team will perform at DWI 1630 Site. The Jacobs ER Team developed this plan following the guidance offered in DOE-EM-STD-5503-94, "EM Health and Safety Plan Guidelines." This plan specifies work practices and engineering controls, the minimum acceptable personal protective equipment (PPE), site control, training requirements, hazard assessment and controls, medical surveillance, exposure monitoring and air sampling, decontamination, and emergency planning that will be used and procedures that will be followed during the activities.

\subsubsection{Scope}

The scope of this H\&S plan includes all field work performed by the Jacobs ER Team in support of the radiological survey of the material inventoried at DWI 1630 Site. This H\&S plan follows guidance established by DOE and the Jacobs ER Team.

\subsubsection{Overview}

Potential hazards associated with the radiological survey activities include physical, biological, radiological, and chemical hazards. The physical and biological hazards exist because the activities occur outdoors. There is a potential for contact with radioactive contaminants through the survey activities. The chemical hazards are associated with the contaminants at the surveyed items or in the ground. However, both radiological and chemical hazards can be limited by the use of appropriate hazard control measures. Because of potentially harmful impacts to workers from failure to adhere to procedural requirements, H\&S violations will not be tolerated. In addition, all personnel participating in site activities will read this document and sign a site roster before beginning work at the site. 


\subsection{KEY PERSONNEL AND ORGANIZATION}

\subsubsection{Key Personnel}

Table 2 lists key personnel associated with this field activity. Figure 5 indicates the project organization, and the following sections describe roles and responsibilities of key individuals.

\subsubsection{Task-Specific Organization}

\subsubsection{Task manager}

The task manager is responsible for executing the overall task, preparing documents, coordinating task activities, and problem resolution. The task manager will also ensure that the H\&S of all project personnel is the primary concern and will be held accountable for adherence to the H\&S plan.

\subsubsection{Field technical representative}

The FTR serves as the representative of the Jacobs ER Team and is expected to provide technical direction to Jacobs ER Team field personnel, document the work performed, and alert the task manager and contract representative about variances from the statement of work. The FTR's duties include monitoring and providing technical direction for the field work, implementing the H\&S plan, maintaining field logbooks, and resolving discrepancies that may arise in the field.

\subsubsection{Program health and safety manager}

The PHSM has primary oversight of the policies and procedures of the H\&S plan and is responsible for the identification and availability of the appropriate monitoring and safety equipment needed to implement the H\&S plan. Additionally, the PHSM must approve a documented task hazard analysis before any work outside the scope of the H\&S plan will be allowed.

\subsubsection{Site health and safety officer}

The SHSO reports to and receives direction from the PHSM, or designee; is responsible for monitoring all aspects of H\&S during field activities; and may modify the requirements of this H\&S plan, with concurrence from the PHSM, by documenting any changes in the H\&S logbook. 
Table 2. Key personnel for the radiological survey of the DWI 1630 Site, Knoxville, Tennessee

\begin{tabular}{|c|c|c|c|}
\hline 61810: & thine & 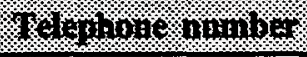 & 3896431014 \\
\hline DOE program manager & A. B. Perkins & $576-2552$ & $564-9985$ \\
\hline Off-site project manager & C. Watson & $220-4812$ & 564-3049 \\
\hline Site task manager & T. Goode & $220-4918$ & $564-9156$ \\
\hline Field technical representative & C. Hickman & $220-4973$ & $564-9160$ \\
\hline Program health and safety manager & S. Burns & $220-4851$ & $996-6375$ \\
\hline Health and safety officer & T. Vasquez & $220-4989$ & $564-9154$ \\
\hline Program QA manager & M. Alewine & $220-4849$ & \\
\hline QA representative & P. Pehrson & $220-4800$ & \\
\hline RADCON manager & S. Green & $220-4839$ & \\
\hline Radiological control specialist & T. Hughes & $220-4951$ & \\
\hline
\end{tabular}

DOE $=$ U.S. Department of Energy

DWI = David Witherspoon, Incorporated

$\mathrm{QA}=$ quality assurance

RADCON = radiation control

The SHSO will conduct an H\&S briefing each day that work will be performed and has the authority to stop work because of H\&S issues. If this authority is exercised, the SHSO will notify the PHSM and task manager as soon as practicable. Work will not resume without PHSM approval.

\subsubsection{Radiological control manager}

The RCM provides oversight to ensure that the policies contained in the Jacobs ER Team RADCON manual (Jacobs ER Team 1996) and the requirements of the Jacobs ER Team Radiation Protection Program are met. The RCM approves radiological work permits, as applicable, according to SOP H\&S-11.1.2.

\subsubsection{Radiological control specialist}

The radiological control (RADCON) specialist provides management oversight for various aspects of the RADCON program as delegated by the RADCON manager. This may include such elements as ALARA, dosimetry, site control, radiological instrumentation, surveys for contamination, radiation and airborne particulates, control of radioactive sources and material, personnel decontamination, radiological assessments, radiological training, and radiological records. 


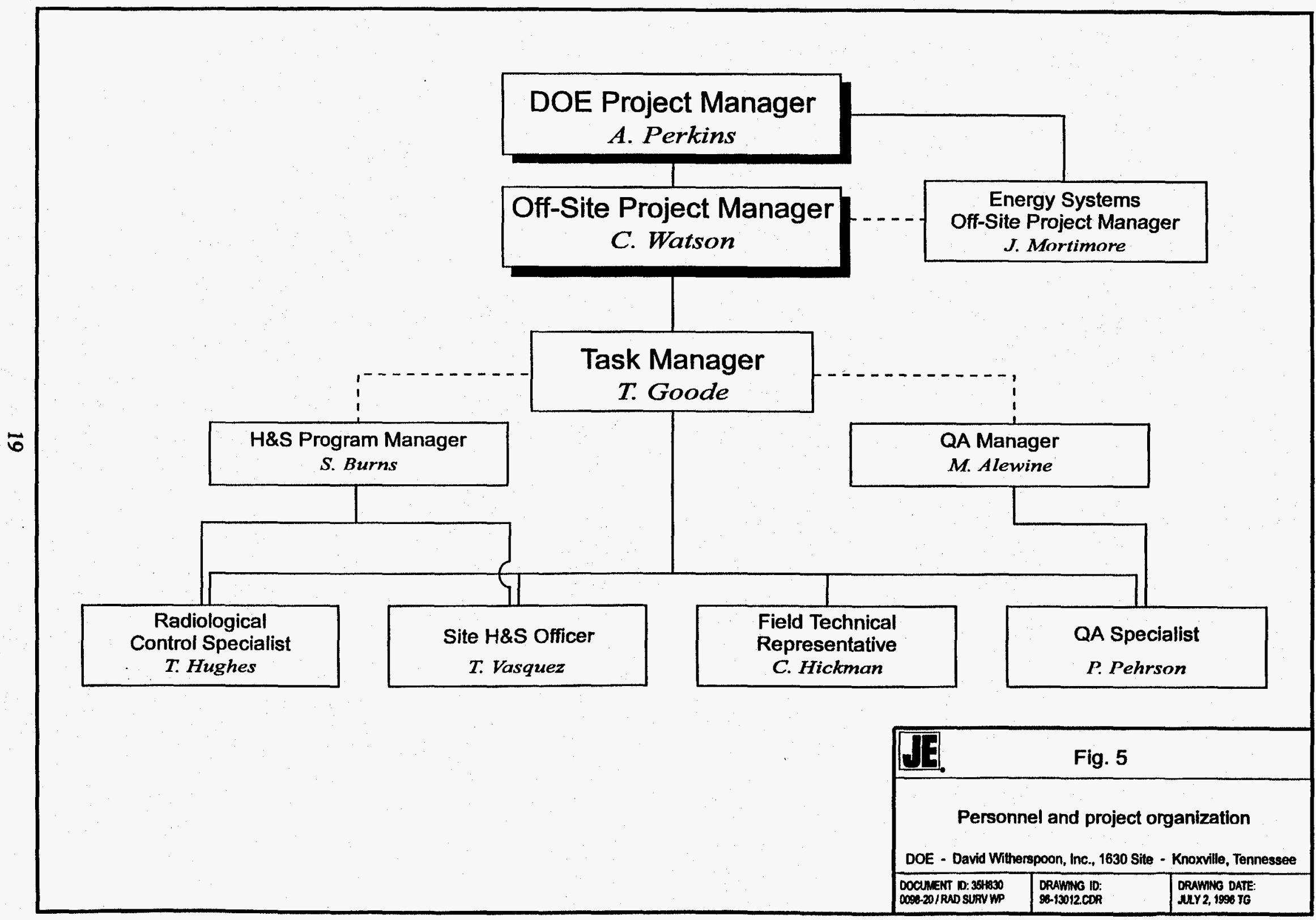




\subsubsection{Radiological control technician}

The RCT ensures that the policies contained in the Jacobs ER Team Radiological Control (RADCON) Manual, Oak Ridge, Tennessee (Jacobs ER Team 1996) and the requirements of the Jacobs ER Team Radiation Protection Program are met. The RCT is responsible for tasks involving such elements as ALARA, dosimetry, site control, radiological instrumentation, surveys for contamination, radiation and airborne particulates, control of radioactive sources and material, personnel decontamination, and radiological records.

\subsubsection{Radiological support technician}

The RST performs tasks associated with the implementation of the RADCON Program. This may include tasks involving such elements as radiological instrumentation, surveys for contamination, radiation and airborne particulates, control of radioactive sources and material, and radiological records.

\subsubsection{Field personnel}

Project personnel involved in the on-site execution of field activities are responsible for taking all reasonable precautions to prevent injury to themselves and to their fellow employees by being alert to potentially harmful situations. Field personnel will perform only those tasks that they can accomplish safely. Any accidents and/or unsafe conditions will be reported immediately to the SHSO. Field personnel will notify the SHSO of special medical conditions (i.e., allergies, contact lenses, pregnancy, or diabetes) and, if necessary, ensure that all on-site personnel are aware of the condition.

Field personnel are also responsible for keeping their work area neat, clean, and orderly to the extent possible and meeting the requirements of this site H\&S plan.

\subsection{HAZARD ASSESSMENT}

\subsubsection{Preliminary Evaluation}

Potential hazards associated with the DWI 1630 Site radiological survey include physical, biological, radiological, and chemical hazards. The physical and biological hazards can be attributed to the environment in which the activity will occur. The radiological and chemical hazards can be attributed to the materials and equipment previously brought to the site. The TDSF's previous technical support contractor performed a RI, which is summarized in a draft report (PRC 1993). The analytical results of this RI indicate that there is chemical contamination 
including PCBs, volatile compounds, semivolatile organic compounds, and metals. Field screening results of surface features indicate radiological contamination higher than background.

\subsubsection{Hazard Identification}

The Jacobs ER Team recently prepared an identifying grid of the DWI 1630 Site and an inventory of the items in each grid. The hazards associated with the survey can be identified and assessed as they apply to one grid area. Table 3 lists the hazards associated with each step and the control measures to be taken in accordance with SOPs H\&S-5.1.1 and H\&S-5.1.2. The following sections discuss the DWI 1630 Site hazards.

\subsubsection{Physical Hazards}

Physical hazards primarily include heat and cold stress, the possibility of slipping or tripping, and strains or sprains from improper lifting. Workers will wear clothing designed to minimize the potential for heat or cold stress when performing any on-site duties. Gloves designed for handling equipment that might cause cuts, abrasions, or pinch points will be used when job conditions warrant. The SHSO will brief the crew on proper lifting technique. Heat and cold stress will be addressed in Section 4.6 of this H\&S plan.

Weather conditions present physical hazards that may change from day to day and will be addressed as part of the daily safety briefing. Conditions that can affect safety include high wind, storms, lightning, sleet, snow, and ice. Each day the SHSO will determine whether work will proceed as dictated by current weather conditions.

\subsubsection{Biological Hazards}

Poison ivy, poison sumac, and poison oak are indigenous to this region. Other potential hazards, as weather warms, are poisonous animals and insects, such as snakes, spiders, and scorpions. Identification of these hazards will be discussed in daily H\&S briefings, as conditions warrant.

\subsubsection{Radiological Hazards}

Radiological hazards can be divided into three separate categories: exposure to sources of radiation, exposure to radioactive contamination, and exposure to airborne radioactivity.

- There is a potential for exposure to sources of radiation at the DWI 1630 Site. Thermoluminescent dosimeters will be worn by all personnel according to SOP H\&S-11.2.1. Additionally, the SHSO or the RADCON technician will monitor for radiation according to SOP H\&S-11.4.2. 
Table 3. Hazard identification and controls for the DWI 1630 Site, Knoxville, Tennessee

\begin{tabular}{lll}
\hline Temeral (mobilization, & $\begin{array}{l}\text { Temperature extremes } \\
\text { Unsafe walking/working } \\
\text { surfaces }\end{array}$ & $\begin{array}{l}\text { Work practices } \\
\text { Training, avoidance }\end{array}$ \\
\hline demobilization) & Poisonous plants & Training, avoidance \\
Traversing site & Adverse weather & Proper PPE, H\&S briefing \\
& Slips, trips, or falls & H\&S briefing \\
& Poisonous animals or insects & H\&S briefing \\
& Chemical contamination & Proper PPE \\
& Radiological contamination & Proper PPE and monitoring \\
& Cuts and scrapes & H\&S briefing and first aid kit \\
& Splash & Proper PPE and safety glasses \\
& & and eyewash \\
\hline
\end{tabular}

DWI $=$ David Witherspoon, Incorporated

$\mathrm{PPE}=$ personal protective equipment

$H \& S=$ health and safety

- There is also a potential for exposure to radioactive contamination at the DWI 1630 Site. During the previous inventory activities, the radiologically contaminated areas on site were identified and posted accordingly. Personnel requiring access to these areas will be required to wear appropriate PPE as determined by the level of contamination in each specific area. The SHSO or RCT will monitor for contamination according to SOP. Additionally, all personnel must monitor for personal contamination according to SOP H\&S-11.4.4, as appropriate.

- Because of the nature of the work, the potential for exposure to airborne radioactivity is virtually nonexistent. However, if questionable conditions exist (e.g., dry topsoil in combination with high winds in a high-contamination area), the SHSO or RCT may monitor for airborne radioactivity according to SOP H\&S-11.4.3.

- To minimize radiation exposure, the Jacobs ER Team has adopted an ALARA policy similar to the DOE policy as spelled out in the Jacobs ER Team Radiological Control (RADCON) Manual, Oak Ridge, Tennessee (Jacobs ER Team 1996). Procedures for implementing this policy can be found in SOP H\&S-11.1.1. 


\subsubsection{Chemical Hazards}

The potential for chemical exposure from this activity is low. The primary avenues of exposure are dermal absorption and ingestion. The survey team will be briefed on these potential hazards during the site-specific H\&S plan training. The possibility of chemical exposure will be mitigated through the use of appropriate PPE. Any hazardous chemicals brought onto the site by the Jacobs ER Team will be handled according to the Jacobs ER Team Hazard Communication Program and the Jacobs ER Team SOP manual, Section H\&S-8, "Chemical Hazards Control."

\subsection{TRAINING}

All personnel who will participate in project field work will be trained as outlined in Chapter 3, "Quality Assurance/Quality Control Project Plan," of this work plan.

\subsection{PERSONAL PROTECTIVE EQUIPMENT}

Potential for exposure to radiological and chemical contaminants is expected to be low for this task. Accordingly, most work will be performed in a modified Level D ensemble. Basic clothing may consist of the following:

- steel-toed work boots,

- full-length pants,

- shirt with sleeves,

- work gloves or surgeons gloves,

- nitrile or neoprene gloves (for PCB test), and

- eye protection.

Respirator protection is not required for the survey activities identified in this plan. The SHSO may upgrade PPE according to the Jacobs ER Team SOP manual, Section H\&S-6 or following consultation with the PHSM. Any upgrades to PPE will be noted in the H\&S logbook.

\subsection{TEMPERATURE EXTREMES}

\subsubsection{Hot Weather Conditions}

Heat stress is caused by interacting factors, including environmental conditions, clothing, workload, and the individual characteristics of the worker. Because heat stress is probably one of the most common (and potentially serious) illnesses at hazardous waste sites, regular 
monitoring and other preventative precautions are vital. The Jacobs ER Team works according to SOP H\&S-9.3.1 for monitoring and safety practices in a hot environment.

\subsubsection{Cold Weather Conditions}

It is expected that this work will be conducted during the summer months; therefore, cold stress should not be a concern at this time. However, should the situation arise where the scope of work continues into the fall/winter months, SOP H\&S-9.3.2 will be followed for monitoring conditions.

\subsection{MEDICAL SURVEILLANCE}

Jacobs ER Team employees participate in the Jacobs ER Team Medical Monitoring Program. The frequency and content of the examinations, records, and documentation are discussed in the following sections.

\subsubsection{Type and Frequency of Examinations}

Examinations are divided into two categories: routine and postexposure. Routine examinations consist of baseline (initial), annual, and baseline (exit). A postexposure examination is performed as needed after a suspected exposure.

\subsubsection{Baseline (initial) examinations}

A baseline (initial) examination is given to each participant before any work assignment involving potential exposure to materials. The complete medical examination is designed to screen for adverse effects from occupational exposure to toxic substances. The examination will include a medical and occupational history review, examination, electrocardiogram, chest X ray, basic blood and urine tests, and a physician's evaluation. In addition, the examination assesses the individual's ability to wear and use PPE.

\subsubsection{Annual examinations}

Each potentially exposed individual receives an examination at least annually. The periodic medical review includes an interim questionnaire, updated hazardous materials exposure summary, and physical examination for comparison to the baseline (initial) examination. The periodic medical examination includes a thorough examination, but without an electrocardiogram or chest $\mathrm{X}$ ray. The physician may request special examination procedures or additional testing if necessary. The request must be approved by the PHSM. 


\subsubsection{Baseline (exit) examination}

Upon terminating employment or leaving the program, the employee must undergo a baseline (exit) examination. The examination is identical to the baseline (initial) examination, but without a respirator fit test.

\subsubsection{Postexposure examination}

Following accidental exposure to hazardous materials, a postexposure examination may be required. The examination may be requested by the exposed individual, task manager, or PHSM. Tests included in the postexposure examination will be determined by the nature of the exposure and may include all tests performed in the baseline (initial) examination with additional tests, as necessary. Postexposure examinations will be established on a case-by-case basis and reviewed by the corporate medical consultant, as appropriate.

\subsubsection{Documentation and Records}

For each employee, the examining physician reports the following to the PHSM:

- approval to work on hazardous waste sites,

- approval to wear a respirator, and

- statement of work restrictions.

The physician retains all other records and upon notice makes them readily available to the employee during regular business hours. The Jacobs ER Team PHSM maintains a copy of the examining physician's report and issues field clearance status for each employee who passes the examination.

\subsection{EXPOSURE MONITORING AND AIR SAMPLING}

\subsubsection{Radiological Monitoring Strategy}

Radiological monitoring will be handled according to the Jacobs ER Team Radiological Control (RADCON) Manual, Oak Ridge, Tennessee (Jacobs ER Team 1996) and SOP manual, Section H\&S-11. The following procedures may be used for radiological monitoring:

- H\&S-11.4.1, "Radiological Contamination Surveys"

- H\&S-11.4.2, "Radiation Exposure Monitoring"

- H\&S-11.4.3, "Radiological Air Sampling and Monitoring".

- H\&S-11.4.4, "Personnel Contamination Monitoring (Frisking)" 


\subsubsection{Instrumentation and Equipment}

Ludlum Model 2221 scaler ratemeters will be used with appropriate probes. The direct reading instruments for ionizing radiation will be a Ludlum Micco- $R$ meter or equivalent. Section 3.4.1 of the QA/QC plan provides a list of SOPs that will be used for instrumentation.

\subsubsection{Physical Monitoring}

When warranted, weather conditions will be monitored daily as specified in SOPs H\&S-9.3.1 and H\&S-9.3.2 (also see Sect. 4.3.3). All personnel working on the DWI 1630 Site project will use the buddy system. No field team member will be without visual or voice contact with at least one other team member.

\subsubsection{Chemical Monitoring}

The equipment radiological survey and walkover survey performed at DWI 1630 Site are nonintrusive in nature. The immunoassay test will be conducted by trained personnel on site. Therefore, chemical monitoring will not be required during the radiological survey.

\subsection{SITE CONTROL}

The radiological aspect of the contaminants of concern represents a greater hazard to the work crew than the chemical aspects, and is, therefore, the driving factor in determining site control. Whereas the entire site will be considered the controlled area, it will not be posted as a RADCON Area, nor will it be fenced for this task because the entire site is not radiologically contaminated.

During the previous inventory activities, areas that were found to be over specified limits (found in Attachment I to SOP H\&S-11.4.1) were posted in accordance with units specified in the Jacobs ER Team Radiological Control (RADCON) Manual, Oak Ridge, Tennessee (Jacobs ER Team 1996) . If any areas are posted as radiological areas, then the SHSO will allow access only to trained and qualified team members and DOE personnel. Personnel working in or visiting these areas will be required to wear PPE and to sign an entry log when entering and leaving.

Visitors who request access to the site will be briefed by the SHSO and escorted while on site. If unauthorized personnel are found on site, the SHSO and FTR will take the following actions:

- Inform the individuals that they have entered a state of Tennessee Superfund site and that the crew is performing activities in support of the site characterization. 
- Request the individuals allow themselves to be frisked, if they have entered a known contamination area.

- If individuals are found to be contaminated, request the individuals allow themselves to be decontaminated according to SOP H\&S-11.6.1.

- Escort the individuals off site.

- Notify local law enforcement officers if the individuals refuse to leave or display aggressive behavior.

- If the unauthorized visitor is found to be contaminated, the occurrence will be reported in accordance with DOE Order 5000.3B.

A support zone will be established on site, including part of the roadway to the site and a designated break area. The break area will have a tarp for workers to get out of the sun, drinking water, toilet facility, and some H\&S equipment, such as an eye wash station, first aid kit, and heat stress monitor, as appropriate. Personnel will be required to frisk per SOP H\&S-11.4.4 before reentering the support zone or leaving the surveyed area.

\subsection{DECONTAMINATION}

\subsubsection{Personnel Decontamination}

Personnel will be decontaminated, as necessary, according to SOP H\&S-11.6.1.

\subsubsection{Equipment Decontamination}

Equipment will be decontaminated, as necessary, according to SOP H\&S-11.6.1 and the Jacobs ER Team SOP manual, Section FS-12.

See Section 5.2 of the waste management plan for details about the fluids generated by decontamination.

\subsection{EMERGENCY RESPONSE/CONTINGENCY PLAN}

Any person discovering an emergency will immediately notify other employees, the SHSO, and the FTR to protect personnel, property, and the environment. The SHSO will verify 
that emergency information is available at each site and that field personnel are adequately trained. Figure 6 presents an emergency situation action plan.

\subsection{EMERGENCY ACTION PLAN}

A cellular telephone will be available on site for emergencies. Any emergency should first be reported to the SHSO, who will call 911 , as necessary. However, any field crew member can call 911 if the situation dictates.

\subsubsection{Emergency Telephone Numbers}

The following are emergency telephone numbers:

- Ambulance, Police, or Fire Department: dial 911

- University of Tennessee Medical Center of Knoxville, 1924 Alcoa Highway:

- Emergency: 544-9401

- Switchboard: 544-9000

- Jacobs ER Team: $220-4800$

- PHSM: 220-4851, pager 966-6375

- Off-site project manager: 220-4812, pager 564-3049

- Task manager: 220-4918, pager 564-9156

Figure 7 shows the route to the nearest hospital.

\subsubsection{Emergency Precautions}

A first aid kit will be readily available, and the SHSO and at least one other field team member will be trained in first aid, CPR, and bloodborne pathogens. Most minor first aid treatment may be rendered on site. In the event of serious injury, call 911 immediately. Report the incident and give location and time. Then proceed to the site trailer to meet the response team. Contact the PHSM as soon as possible. Other precautions include the following:

- A copy of this H\&S plan and the site map with emergency route will be readily available. 


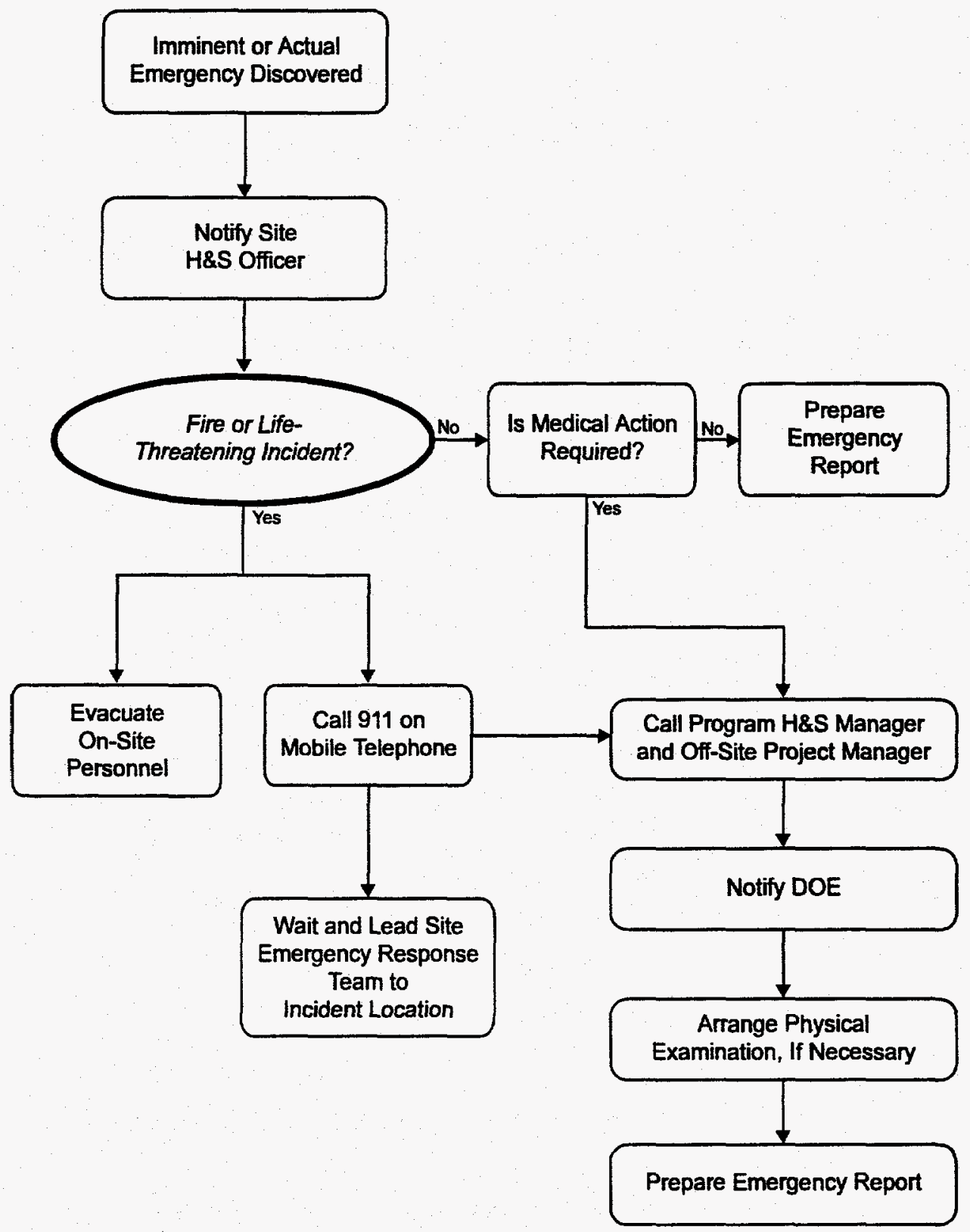

\begin{tabular}{|c|c|c|}
\hline \multicolumn{3}{|c|}{ Fig. 6} \\
\hline \multicolumn{3}{|c|}{ Emergency situation action plan } \\
\hline DOE - David Wi & spoon, Inc., 1 & inoxville, Tennessee \\
\hline $\begin{array}{l}\text { DOCUMENT ID: } 35 \text { HE30 } \\
\text { DOAB-20/RAD SURV WWP }\end{array}$ & $\begin{array}{l}\text { DRAWING ID: } \\
\text { 96-13011.CDR }\end{array}$ & $\begin{array}{l}\text { ORAWHAG DATE: } \\
\text { JUYY 2, } 1986 \text { TG }\end{array}$ \\
\hline
\end{tabular}




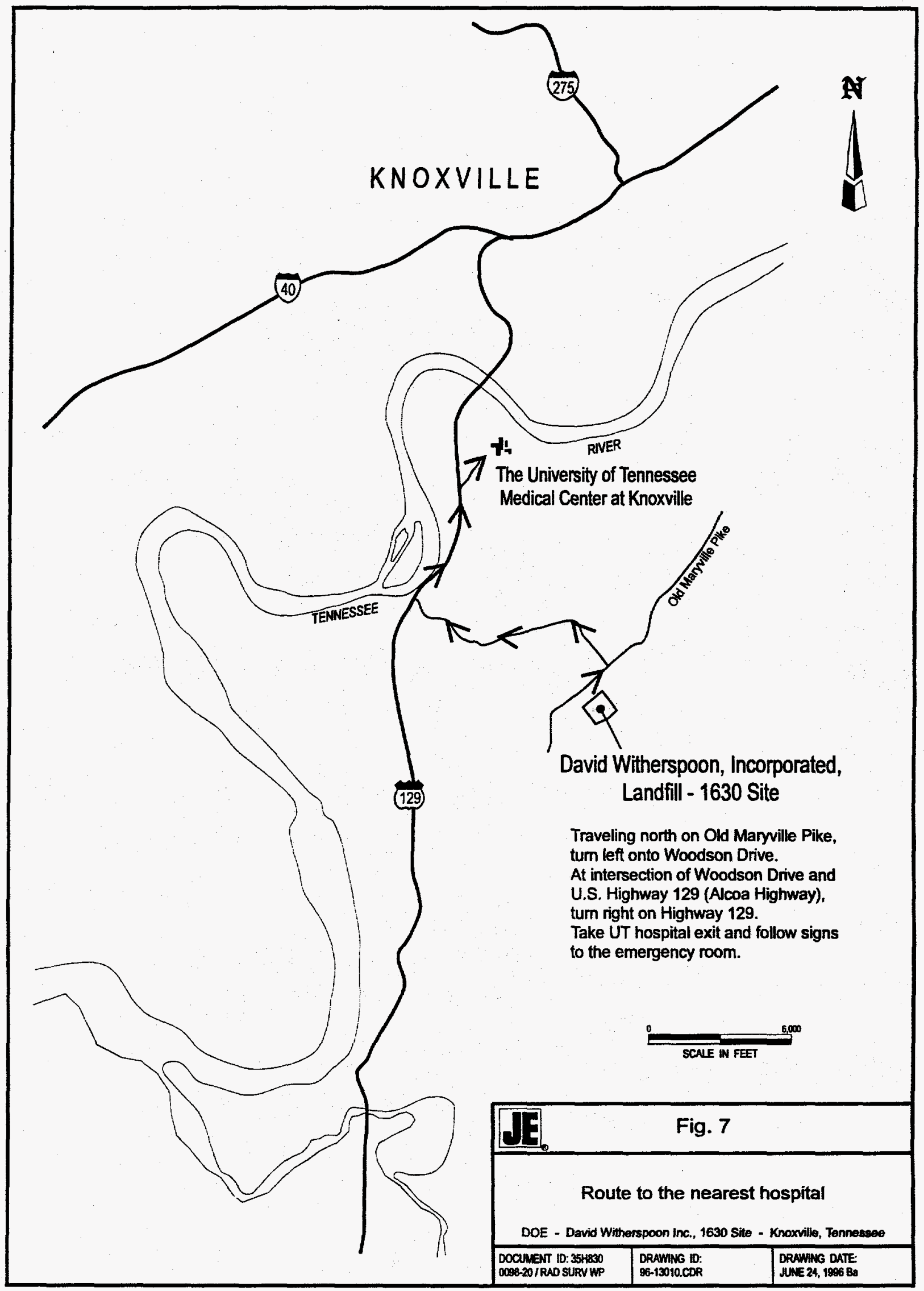


- All injuries, no matter how trivial they may seem to the individual, will be reported as soon as possible to the SHSO.

- The Jacobs ER Team Bloodborne Pathogens Program will be followed by all field team personnel rendering first aid.

\subsection{CONFINED SPACE ENTRY}

Confined space entry is not applicable to this activity.

\subsection{SPILL CONTAINMENT}

Spill containment will be applicable only to the decontamination of equipment and will be handled according to the decontamination procedures mentioned in Section 4.10.

\section{WASTE MANAGEMENT PLAN}

\subsection{WASTE-HANDLING RESPONSIBILITIES}

\subsubsection{Jacobs ER Team}

The Jacobs ER Team will prepare the work plan, which includes final disposition of PCB waste, PPE, sanitary waste, and any solid low-level waste (SLLW).

\subsubsection{Lockheed Martin Energy Systems}

Lockheed Martin Energy Systems (Energy Systems) (Off-Site ER) will coordinate meetings with Energy Systems Waste Management personnel to plan disposition of PPE, sanitary trash, and potential SLLW. In addition, Energy Systems will provide contingency planning for decontamination fluid, which will include transportation to Energy Systems, if required.

\subsection{WASTE-GENERATING ACTIVITIES}

This project will manage all waste streams according to Guidance to Management of Investigation-Derived Wastes (EPA 1991). The primary purpose of this survey is to document the radiological condition of the equipment on site. Wastes generated during the equipment survey include PCB waste, PPE, potential SLLW, and sanitary trash. PCB waste will be generated by the on-site PCB immunoassay test. PPE will be generated by workers and visitors to the site. The sanitary trash will be generated from site mobilization. Any potential SLLW 
will be generated by the radiological technicians through the use of smears for radiological contamination. All generated waste will be handled according to SOP FS-11.1. If decontamination is required, all decontamination fluids will be contained in open-top, 55-gal drums and placed in the staging area.

\subsection{WASTE HANDLING AND CHARACTERIZATION}

The PCB waste will be generated through the on-site PCB immunoassay test, which includes PCB-contaminated liquid, cloth and paper wipes used in the sampling, and some laboratory waste such as filters, bulb pipettes, tips, and tubes. The PCB-contaminated liquid will be stored in a separate container from the other liquid generated by the test. Cloth, paper wipes, and other test-generated waste will be collected and disposed as PCB waste.

The PPE generated from this activity will be surveyed for beta-gamma-emitting contaminants and will be considered sanitary trash if no contamination is detected. Any PPE or radiological swipes with activity levels over MDA will be considered SLLW. All waste will be segregated, containerized, and labeled appropriately and will remain on site for the duration of all field activities conducted by the Jacobs ER Team, including this radiological survey. Transport and final disposition of wastes will be coordinated with Energy Systems Waste Management.

\subsection{WASTE STAGING}

One staging area will be set up within a fenced area to accommodate wastes generated on site. This area will have the following at a minimum:

- visibly marked boundaries of the field staging area,

- arrangement of the field staging areas to accommodate inspection, and

- management of material in containers according to all applicable regulations.

\section{REFERENCES}

EPA (U.S. Environmental Protection Agency). 1991. Guidance to Management of Investigation Derived Wastes. Office of Solid Waste and Emergency Response, Washington, DC.

Jacobs ER (Environmental Restoration) Team. 1996. Jacobs ER Team Radiological Control (RADCON) Manual, Oak Ridge, Tennessee. Oak Ridge, TN. 
PRC (PRC Environmental Management, Incorporated). 1993. Draft Technical

Memorandum. Phase I Remedial Investigation Witherspoon Landfill Site, Knoxville, Tennessee. Knoxville, TN.

TDSF (Tennessee Division of Superfund). 1990. Site Inspection of the Witherspoon Landfill Superfund Site. Knoxville, TN. 